International Journal of Management Science and Business Administration

Volume 2, Issue 3, February 2016, Pages 33-42

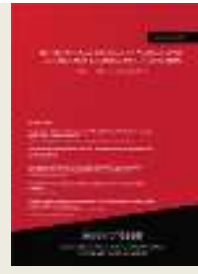

DOI: $10.18775 /$ ijmsba.1849-5664-5419.2014.23.1004

http://dx.doi.org/10.18775/ijmsba.1849-5664-5419.2014.23.1004

\title{
The Impact of Strategic Learning Orientation, Entrepreneurial Orientation and Reconfiguring Capabilities on Export Performance of SMEs in Nigeria
}

\author{
Tope Samson Abiodun, Muhammed Isa KIDA \\ Graduate School of Business, Universiti Utara Malaysia, 06010UUM Sintok, Kedah, Malaysia \\ Correspondent Author's e-mail: samsontope@yahoo.com
}

\begin{abstract}
The objectives of this study are to investigate the relationship between learning orientation (LO), entrepreneurial orientation (EO), reconfiguring capability (RC) and export performance (EP) as well as determine the mediating effect of entrepreneurial orientation on the relationship between LO, RC and EP of SMEs in Nigeria. Having employed PLS-SEM on 201 data from SMEs in Nigeria, the findings of the study revealed significant relationship between LO and EP, between RC and EP, and between EO and EP, while the mediating effect of EO on the relationship between LO and EP, and between RC and EP are less statistically significant
\end{abstract}

Keywords: Entrepreneurial orientation, Reconfiguring capability, Learning orientation, Small and medium enterprises, Export performance

\section{Introduction}

The need for economic growth has made SMEs' significant roles to be recognized in many nations. Their values, such as power of expansion, Job creations at relatively low capital cost, means of livelihood, provision and development of trained and untrained labor for potential industrial growth and the breeding ground for managerial and entrepreneurial talents have shown SMEs as indispensible sector in any economy (Ayanda \& Laraba, 2011). However, SMEs in Nigeria face monumental challenges such as weak strategic orientations, poor infrastructure, inadequate capabilities, poor management and inadequate technological skills' development and lack of export market knowledge/experience (Adegbite, Ilori, Irefin, Abereijo, \& Aderemi, 2007).

A study carried out by Manufacturing Association of Nigeria (MAN) showed that just about 10 percent of industries run by its members are completely in operation. The vast majority of SMEs die before their first to five year of operation, while some disappear within sixth and tenth year of existence and the remaining ones that grow to maturity are less than five to ten percent (Onugu, 2005). Economic and industrial growth as development goals can only be attained by promoting export development of Small and Medium Enterprises (Kazem \& van der Heijden, 2006). SMEs account for 25-35 percent of world's manufactured export and their contribution to GDP is between four and six percent (Ibeh, 2004). In spite of the importance of export development and SMEs' relationship with economic development, scholarly interest has neglected how an emerging firms should decide what resources to amass and how to configure them to create customer value in a context of uncertainty in international arena (Santos \& Eisenhardt, 2009). The bulk of researches on strategic orientations and reconfiguring capabilities in export performance focus on large established firm (Corner \& Wu, 2012).

Many of these researches focus on firms operating in western developed market and little is known about Reconfiguring capability and strategic orientations and their relationship with export performance in transition economies. As such, little is known about export development of SMEs (Sapienza, Autio, George, \& Zahra, 2006). 
Wang and Ahmed (2007) Suggested that researchers should develop more refine measure of adaptive capabilities by considering specific aspects of dynamic capabilities such as resources reconfiguration and examine it in a systematic network and provide a better understanding of what circumstances and how firms should direct their resources and capabilities in search of competitive advantage. Hence, the basic objectives of this study are to explain and predict export performance of SMEs with strategic learning orientation, entrepreneurial orientation and reconfiguring capability through the lens of dynamic capability view and resource based view (RBV).

\section{Underpinning Theories}

1. Resources Based View

2. Dynamic Capability View

This study considers entrepreneurial orientation as a sufficient tool to mediate between learning orientation and export performance of SMEs based on the premises that firms are proactive organization and manager makes decision on structural change in order to learn, find new opportunity and be profitable (Karim, 2006). Entrepreneurial orientation would give explanation on why the managers of smaller organization need to learn, since he plays the significant roles in shaping the firm's future. For export firm in today's dynamic environment to achieve competitive advantage depends on its capacity to learn, knowing how to store and how to recover a good memory bank and apply it. Hence, this study hypothesizes that:

\section{H5: Entrepreneurial orientation mediates the relationship between learning orientation and export performance.}

\section{Methodology}

The data collection for this study took place in Nigeria, because of the call for the development of non-oil sector and low performance of Nigeria's SMEs in export venture. Each of the manufacturing SMEs identified in the directory Manufacturing Association of Nigeria (MAN) were contacted by telephones to identify an appropriate key informant for the study and inform the firm about the research project (Morgan, Kaleka, \& Katsikeas, 2004). About 2200 firms were identified as qualified because they met the criteria specified. To select a sample size for the population of 2200 , Krejcie and Morgan (1970) sample sizes determination's table was used. The table showed that 331 sample sizes would be required for the population of 2200 and additional $40 \%$ of 331 were added to make provision for response bias, making 457 sample sizes.

Having employed proportional stratified and systematic sampling, the distribution of the questionnaires was based on the proportion of population of SMEs' export manager in each geographical area and systematic selection of the respondents from the list of SMEs' exporter in order to ensure representative distribution. About twenty five days after the questionnaire have been emailed to the respondents, 118 completed questionnaires were received through e-mail and these 118 questionnaires were regarded as early responses which (after non useable ones have been removed) were further used to assess non response bias on the actual variables. In order to improve the response rate, a follow-up phone calls and series of Short Message Service (SMS) were sent to remind the exporting managers who were yet to return their questionnaires. This effort yielded the largest numbers of response compared to the first response. About 120 questionnaires were returned. It was tagged as late responses which (after non useable ones have been removed) were later used to assess non-response bias.

Out of 457 questionnaires that were emailed to the selected respondents, a total of 238 were returned, 156 questionnaires were returned from Lagos, 58 from Kano and 24 from Aba respectively out of these 238 questionnaires 2 were not usable due to excessive missing data, 2 were completely eliminated due to their selection of option 'services/government' and not 'manufacturing' as primary area of business, 2 were also removed for selection of option 'total cost of business that above \#200,000,000 Naira specified as a criteria for SMEs and 2 were also eliminated due to low level of knowledge on the topic of interest, remaining 230 useable questionnaire. Hence, the response rate was calculated as 50\% which is sufficient for the study (Sekaran \& Bougie, 2013). 


\section{Measures}

Learning Orientation (LO) was measured with Baker and Sinkula (1999). The items in the scale really suit the purpose of this study because Learning orientation is a set of values that affect the satisfaction of a firm (Argyris \& Schon, 1978). The degree to which firms are likely to promote generative learning as competency is influenced by its culture of learning orientation (Sinkula, Baker, \& Noordewier, 1997) Learning orientation is reflected when old assumptions are challenged and set of knowledge-questioning values that have been held in the organization (Bettis \& Prahalad, 1995; Sinkula et al., 1997). All values that are routinely associated with organizational learning capabilities revolved around its commitment to learning, open-mindedness and shared vision (Baker \& Sinkula, 1999).

The reconfiguring capabilities in this study were examined from two different perspectives: the amount of reconfiguring activity over the past three years and the perceived success in implementing the activities. Jantunen et al. (2005) used the success of renewal activities carried out in the community innovation survey of the European Union. This list comprises seven renewal types (organization structure, business strategy and manufacturing process). Some of the activities performed ranged from zero to seven. This study employed the seven items to measure reconfiguring capability.

Entrepreneurial orientation was measured with nine items of Covin and Slevin (1989). The vast majority of studies related to EO used only reactiveness, risk taking and innovativeness (George \& Marino, 2011) which are version of the scale suggested by Covin and Slevin (1989). Moreover, Jantunen et al. (2005) realized that the three dimensions are closely related through the composite measure constructed as an average of all nine items which resulted in reliability coefficient of .74. The guidelines regarding composite reliability considered this satisfactory (Nunnally, 1978). Hence, this study adapted the nine items' measure of Covin and Slevin 1989 for parsimony and credibility

The measurement of export performance has not been universally suggested among the scholars of export's researchers, however, Zou, Taylor, and Osland (1998) addressed the three critical issues in determining export performance, their scale EXPERF was multidimensional and really centered on performance of exporting ventures. It was built on Cavusgil and Zou (1994) and comprises three basic dimensions that are rooted in export performance's literatures; financial, strategic and satisfaction's export performance measure. The nine items adapted from Zou et al., (1998) are used to measure export performance in this study because they reflect economic and non-economic factor that could easily show the performance of SMEs.

\section{Analysis}

The present study employed a two-step process to calculate and report the result of PLS-SEM path as suggested by (Henseler, Ringle, \& Sinkovics, 2009). Having run PLS-SEM algorithm, the indicators with outer loading were between 0.4299 and 0.8702, and this shows individual items reliability (Hair, Hult, Ringle,Sarstedt, \& 2013). The composite reliability of the study ranged between 0.7970 and 0.8702 which is considered satisfactory for internal consistency validity (Bernstein \& Nunnally, 1994). The average variance extracted range between 0.521 and 0.7948 , which are all above the cut off .50. Table 1 shows the items loadings, average Variance Exracted and the composite reliability of the study.

Table 1: Items Loadings, Average Variance Extracted and Composite Reliability for the constructs

\begin{tabular}{|c|l|r|r|r|}
\hline Latent Variable & Items & \multicolumn{1}{c|}{ Loadings } & \multicolumn{1}{c|}{ AVE } & Composite Reliability \\
\hline Commitment to Learning & CLO01 & 0.8359 & 0.5871 & \\
\hline & CLO02 & 0.8073 & & \\
\hline & CLO03 & 0.8376 & & \\
\hline & CLO04 & 0.5444 & & \\
\hline Open-mindedness & SLO01 & 0.797 & & \\
\hline & SLO02 & 0.7955 & & \\
\hline & SLO03 & 0.7422 & & \\
\hline
\end{tabular}


Tope Samson Abiodun

The impact of strategic learning orientation, entrepreneurial orientation and reconfiguring capabilities on export performance of SMEs in Nigeria

\begin{tabular}{|c|c|c|c|c|}
\hline & SL005 & 0.5246 & & \\
\hline \multirow{7}{*}{ Entrepreneurial Orientation } & EOO01 & 0.6968 & 0.5479 & 0.858 \\
\hline & EOO04 & 0.7122 & & \\
\hline & EOO05 & 0.7987 & & \\
\hline & EOO06 & 0.7098 & & \\
\hline & EOO07 & 0.7654 & & \\
\hline & EOO08 & 0.7768 & & \\
\hline & EOO09 & 0.7778 & & \\
\hline \multirow[t]{7}{*}{ Reconfiguring Capability } & RCD01 & 0.5816 & 0.6568 & 0.9296 \\
\hline & RCD02 & 0.8483 & & \\
\hline & RCD03 & 0.8816 & & \\
\hline & RCD04 & 0.8619 & & \\
\hline & RCD05 & 0.769 & & \\
\hline & RCD06 & 0.8581 & & \\
\hline & RCD07 & 0.8318 & & \\
\hline \multirow[t]{3}{*}{ Satisfaction } & SAT01 & 0.9382 & 0.7948 & 0.9207 \\
\hline & SAT02 & 0.869 & & \\
\hline & SAT03 & 0.8654 & & \\
\hline \multirow[t]{3}{*}{ Strategy } & STG01 & 0.6995 & 0.6883 & 0.8675 \\
\hline & STG02 & 0.8998 & & \\
\hline & STG03 & 0.8752 & & \\
\hline \multirow[t]{3}{*}{ financial } & FIN01 & 0.6995 & 0.6924 & 0.8702 \\
\hline & FIN02 & 0.8998 & & \\
\hline & FIN03 & 0.8752 & & \\
\hline
\end{tabular}

The square root of the average variance extracted ranged between 0.7218 and 0.8915 which were all greater than the correlation among the latent constructs, signifying sufficient discriminant validity (Chin, 1998; Fornell \& Larcker, 1981). Table 2 shows the square root of the variance extracted and correlations of the latent variables.

Table 2: Square Root of Average Variance Extracted and Correlations of the latent Variables

\begin{tabular}{|c|c|c|c|c|c|c|c|c|}
\hline Latent Constructs & 1 & 2 & 3 & 4 & 5 & 6 & 7 & 8 \\
\hline Commitment to $\mathrm{L}$ & 0.7662 & & & & & & & \\
\hline Entrepreneurial O & 0.3074 & 0.7402 & & & & & & \\
\hline Open-mindedness & 0.5819 & 0.3268 & 0.7218 & & & & & \\
\hline Reconfiguring $\mathrm{C}$ & 0.061 & 0.3008 & 0.0083 & 0.8104 & & & & \\
\hline Satisfaction & 0.0634 & 0.3131 & -0.0729 & 0.5355 & 0.8915 & & & \\
\hline Shared Vision & 0.3836 & 0.3983 & 0.2998 & 0.0546 & 0.2954 & 0.7076 & & \\
\hline Strategy & 0.1314 & 0.289 & -0.0557 & 0.5661 & 0.6482 & 0.205 & 0.8296 & \\
\hline financial & 0.3061 & 0.2987 & 0.1893 & 0.4955 & 0.5833 & 0.2156 & 0.6976 & \\
\hline
\end{tabular}

Note: Diagonal elements (figures in bold) are the square root of the variance shared the constructs and their measures while off diagonal elements are the correlations among constructs.

The effect size of each of the constructs on endogenous construct, large with F squared of 0.5043 and small with F. squared of 0.0223 . The cross validated redundancy for endogenous variables are 0.2247 and 0.135 which are greater 
than zero and considered to have predictive relevance (Henseler et al., 2009). Standard bootstrapping procedure was used with a number of 5000 bootstrap samples and 201 cases to assess the significance of the paths (Henseler et al., 2009; Hair et al., 2013). Figure 3.1 depicts the use of boostrapping to assess the significance of the path coefficients and Table 3.1 shows the result of the structural model.

Table 3: The Result of the structural Model and Mediator

\begin{tabular}{|c|c|c|c|c|c|}
\hline $\mathbf{H}$ & Relationship & $\beta$ eta & Standard Error & T. Value & P. value \\
\hline H1 & Learning Orientation -> Export $\mathrm{P}$. & 0.1262 & 0.0626 & 2.0146 & 0.02 \\
\hline H2 & Reconfiguring C. ->Export P. & 0.5713 & 0.0811 & 7.0453 & 0.00 \\
\hline H3 & Entrepreneurial O.-> Export P. & 0.1221 & 0.0823 & 1.4831 & 0.06 \\
\hline H4 & $\begin{array}{l}\text { Reconfiguring } \quad \mathrm{C}->\text { Entrepreneurial } \\
\text { >Export } \mathrm{P} \text {. }\end{array}$ & 0.2874 & 0.0713 & 1.3589 & 0.09 \\
\hline H5 & Learning O->Entrepreneurial O.->Export $\mathrm{P}$ & 0.4051 & 0.0636 & 1.4316 & 0.08 \\
\hline
\end{tabular}

$* * * \mathrm{P}<0.00 ; * * \mathrm{P}>0.05: * \mathrm{P}<0.01$

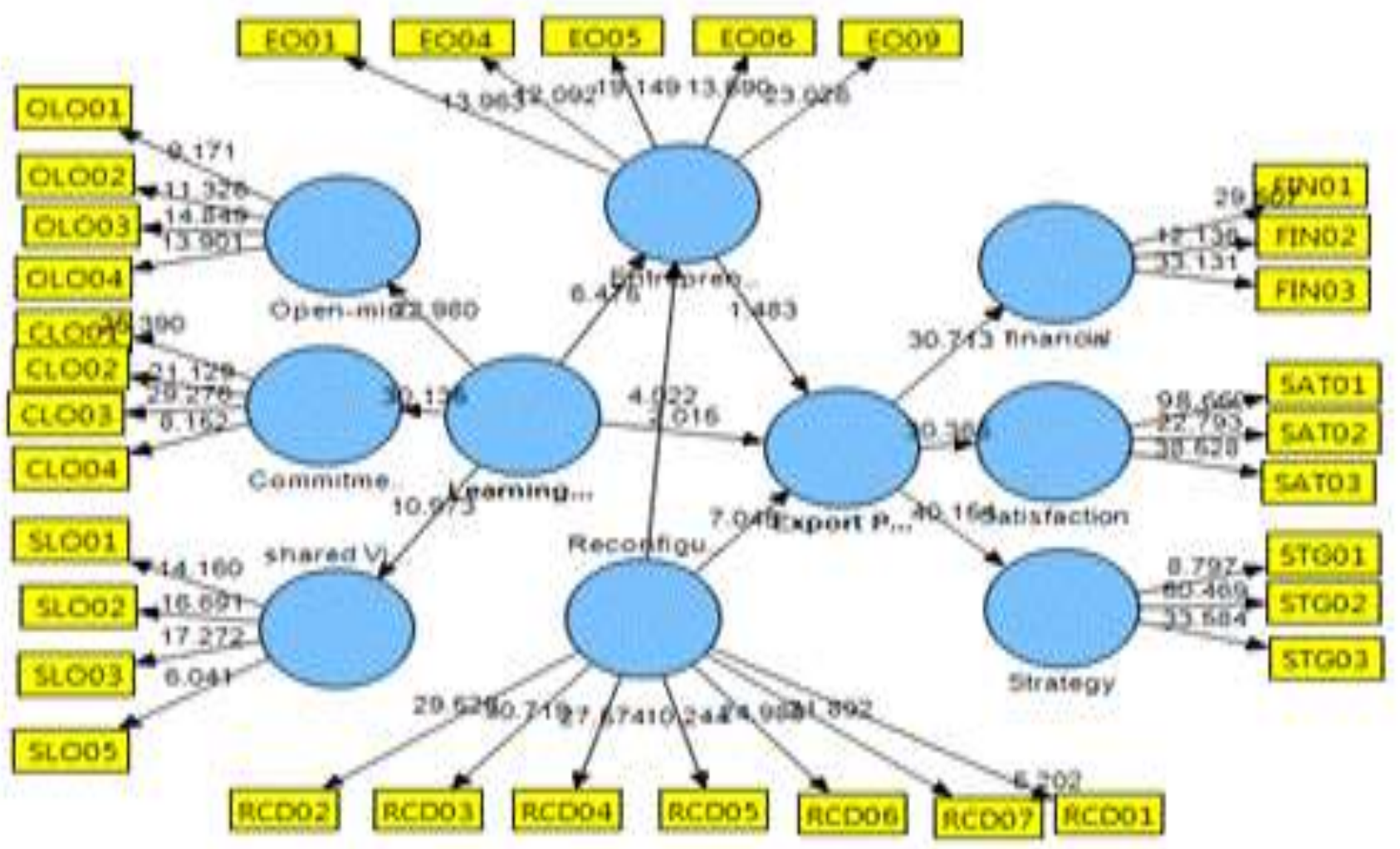

Figure 1: The full Structural Model

\section{Discussion}

The result $(\beta=0.1262, \mathrm{t}=2.0146, \mathrm{p}<0.02)$ of the relationship between learning orientation and export performance in the study is consistent with the previous studies (Akyol \& Akehurst, 2003; Cadogan, Cui, \& Li, 2003; Day, 1992; Song, Joo, \& Chermack, 2009; Souchon et al., 2012). Ability to learn and apply this knowledge to turbulent environment and challenge export market is the major key to achieve and sustained competitive advantage (Day, 1992). Secondly, the outcome of PLS model's estimate $(\beta=0.5713, \mathrm{t}=7.0453, \mathrm{p}<0.00)$ on the relationship between reconfiguring capability and export performance returned statistically significance result to support the hypothesis. This finding is consistent with prior study (Abiodun \& Rosli, 2014), and the findings of this study provide empirical support for dynamic capability theory which lays emphasis on the ability to orchestrate change and reconfigure the asset base in order to 
take the advantage of new opportunity (Jantunen, et al., 2005). Thirdly, the result $(\beta=0.1221, \mathrm{t}=1.4831, \mathrm{p}<0.06)$ is also consistent with earlier studies (Baker \& Sinkula, 2009; Balabanis \& Katsikea, 2003; Boso, Cadogan, \& Story, 2012; Calantone, Kim, Schmidt, \& Cavusgil, 2006; Cavusgil, 1984; Lechner \& Gudmundsson, 2014; Wiklund \& Shepherd, 2003; Zahra \& Covin, 1995) which suggested relationship exists between entrepreneurial orientation and firm/export performance. Fourthly, the mediating effect calculated through the spreadsheet of coefficient generated by war PLS (Kock, 2014), indicates that $(\beta=0.2874, \mathrm{t}=1.3589, \mathrm{p}<0.09)$ entrepreneurial orientation mediate between reconfiguring capability and export performance. The ownership perception of opportunities is used to underpin changes in existing routines or resources configuration, their willingness to undertake such changes and their ability to implement the change. (Woldesenbet, Ram, \& Jones, 2012). Fifthly, the mediating effect calculated through the spreadsheet of coefficient generated by war PLS (Kock, 2011), the result $(\beta=0.4051), t=1.4316, p<0.08)$ shows that entrepreneurial orientation mediate the relationship between learning orientation and export performance. This is consistent with the view that Entrepreneurial orientation would give explanation on why the managers of smaller organization need to learn, since he plays the significant roles in shaping the firm's future (Souchon et al., 2012). However, p. value; 0.08 at one Tale significant level for mediation of EO relationship between LO and EP did not reflect good significant mediating effect. The same thing applicable to $\mathrm{P}$ Value; 0.09 and $\mathrm{P}$ Value; 0.06 respectively, which means there is no strong mediating effect and each of the variable could directly have impact on export performance without EO. Nevertheless, this study has been able to show the level of the significance that could be attained when EO is used as mediator between these constructs.

\section{Conclusion}

This study makes contribution to the literature of entrepreneurship and strategic management research by investigating the impact of reconfiguring capabilities and strategic learning and entrepreneurial orientation on export performance of SMEs. To the best of the knowledge of this study, these effects have not been empirically investigated in previous study in this approach. Even though there have been studies on strategic orientations and export performance (Cadogan, 2012; Knight \& Cavusgil, 2004).This study in particular complements the existing study and the result suggests that it is not only the ability to learn and apply this knowledge and challenge export market old assumptions to achieve and sustain competitive advantage (Day, 1992), but also the ability of firm to create new asset configuration that have strategic impact on export performance. The findings of this study provide empirical support for dynamic capability view which lays emphasis on the ability to orchestrate change and reconfigure the asset base in order to take the advantage of new opportunity (Jantunen, et al., 2005). Reconfiguring capability significantly related to export performance, shows that reconfiguring capabilities are learned and stable blueprint of combined activities through which the organization steadily generates and transform its operating routines in order to improve efficiency and effectiveness (Zollo \& Winter, 2002). This finding has also joined the host of prior studies on learning orientation to subscribe that learning orientation -export performance implication represents area of building a cumulative body of relevant knowledge about entrepreneurship and stresses the fact that exporting SMEs are likely to benefit from pursuing learning orientation.

Entrepreneurial orientation mediates the relationship between reconfiguring capability, learning orientation and export performance, which denotes that reconfiguring capability and learning orientation possessed by an exporting entrepreneur would identify new combination of productive resources within the firm and extend the frontiers of capability, and connecting several ventures with different resources and enhance the ongoing adaptation of exporting since the linkage improves overall innovation management that would enable the firm to reconfigure its resources and provide way to experiment new idea (Borch \& Madsen, 2007; Dougherty \& Hardy, 1996).

Therefore, Manager who put relatively more emphasis on profitability could invest more in reconfiguring their assets Such SMEs' manager could emphasize capability development and market penetration in their exporting activities as such effort would enhance processes needed to learn from disappointment, recognition of failure, interpretation of result into exporting model that can be tested and better action taking routine in export arena. Firms should also be proactive, innovative, and strategic and take measure of calculated risk to improve their export performance. Managers should recognize that their ability to adapt to external environmental changes is only the key driver to sustainable export performance. 
Hence, skills should be honed to spot growth options from other development initiatives, executing reconfiguring option required different operating capabilities that have to be reconfigured, coordinated and integrated for maximum competitive advantage in export arena (Newey \& Zahra, 2009). The managerial implication of learning orientation impact on export performance implies that export growth is optimal at very high levels of response to export information which is promoted by commitment to learning, open-mindedness, shared vision, acquisition and distribution of export information and management of mental model.

\section{References}

- Abiodun, T. S., \& Rosli, M. (2014). The mediating effect of reconfiguring capabilities on the relationship between entrepreneurial orientation and export performance of small and medium enterprises. European Journal of Business and Management, 6(34), 345-357.

- Adegbite, S., Ilori, M., Irefin, I., Abereijo, I., \& Aderemi, H. (2007). Evaluation of the impact of entrepreneurial characteristics on the performance of small scale manufacturing industries in Nigeria. Journal of Asia Entrepreneurship and Sustainability, 3(1), 1-22.

- Akyol, A., \& Akehurst, G. (2003). An investigation of export performance variations related to corporate export market orientation. European Business Review, 15(1), 5-19, CrossRef

- Argyris, C., \& Schon, D. (1978). Organizational learning: A theory of action research. Reading, MA: Addison-Wesley, 1, 978.

- Autio, E., Sapienza, H. J., \& Almeida, J. G. (2000). Effects of age at entry, knowledge intensity, and imitability on international growth. Academy of management journal, 43(5), 909-924, CrossRef

- Ayanda, A. M., \& Laraba, A. S. (2011). Small and medium scale enterprises as a survival strategy for employment generation in Nigeria. Journal of Sustainable Development, 4(1), p200.

- Baker, W. E., \& Sinkula, J. M. (1999). The synergistic effect of market orientation and learning orientation on organizational performance. Journal of the academy of marketing science, 27(4), 411-427, CrossRef

- $\quad$ Baker, W. E., \& Sinkula, J. M. (2009). The Complementary Effects of Market Orientation and Entrepreneurial Orientation on Profitability in Small Businesses*. Journal of Small Business Management, 47(4), 443-464, CrossRef

- Balabanis, G. I., \& Katsikea, E. S. (2003). Being an entrepreneurial exporter: does it pay? International Business Review, 12(2), 233-252, CrossRef

- $\quad$ Barkema, H. G., Shenkar, O., Vermeulen, F., \& Bell, J. H. (1997). Working abroad, working with others: How firms learn to operate international joint ventures. Academy of Management journal, 40(2), 426-442, CrossRef

- Bernstein, I. H., \& Nunnally, J. (1994). Psychometric theory. New York: McGraw-Hill.

- Bettis, R. A., \& Prahalad, C. K. (1995). The dominant logic: Retrospective and extension. Strategic management journal, 16(1), 5-14, CrossRef

- Bhuian, S. N., Menguc, B., \& Bell, S. J. (2005). Just entrepreneurial enough: the moderating effect of entrepreneurship on the relationship between market orientation and performance. Journal of business research, 58(1), 9-17, CrossRef

- Blesa, A., Ripollés, M., \& Monferrer, D. (2007). Entrepreneurial and market orientations and international performance of Spanish and Belgian international new ventures. Paper presented at the 36th EMAC Conference.

- $\quad$ Bontis, N., Crossan, M. M., \& Hulland, J. (2002). Managing an organizational learning system by aligning stocks and flows. Journal of management studies, 39(4), 437-469, CrossRef

- Borch, O. J., \& Madsen, E. L. (2007). Dynamic capabilities facilitating innovative strategies in SMEs. International Journal of Technoentrepreneurship, 1(1), 109-125, CrossRef

- Boso, N., Cadogan, J. W., \& Story, V. M. (2012). Entrepreneurial orientation and market orientation as drivers of product innovation success: A study of exporters from a developing economy. International Small Business Journal, 0266242611400469.

- Brockman, B. K., \& Morgan, R. M. (2003). The role of existing knowledge in new product innovativeness and performance. Decision Sciences, 34(2), 385-419, CrossRef

- $\quad$ Brown, T. E., Davidsson, P., \& Wiklund, J. (2001). An operationalization of Stevenson's conceptualization of entrepreneurship as opportunity-based firm behavior. Strategic Management Journal, 22(10), 953-968, CrossRef

- Cadogan, J. W. (2012). International marketing, strategic orientations and business success: Reflections on the path ahead. International Marketing Review, 29(4), 340-348, CrossRef

- Cadogan, J. W., Cui, C. C., \& Li, E. K. Y. (2003). Export market-oriented behavior and export performance: the moderating roles of competitive intensity and technological turbulence. International Marketing Review, 20(5), 493-513, CrossRef 
- Calantone, R. J., Kim, D., Schmidt, J. B., \& Cavusgil, S. T. (2006). The influence of internal and external firm factors on international product adaptation strategy and export performance: a three-country comparison. Journal of Business Research, 59(2), 176-185, CrossRef

- Cavusgil, S. T. (1984). Differences among exporting firms based on their degree of internationalization. Journal of Business Research, 12(2), 195-208, CrossRef

- Cavusgil, S. T., \& Zou, S. (1994). Marketing strategy-performance relationship: an investigation of the empirical link in export market ventures. The Journal of Marketing, 1-21, CrossRef

- Chin, W. W. (1998). Commentary: Issues and opinion on structural equation modeling: JSTOR.

- Chmielewski, D. A., \& Paladino, A. (2007). Driving a resource orientation: reviewing the role of resource and capability characteristics. Management Decision, 45(3), 462-483, CrossRef

- Corner, P. D., \& Wu, S. (2012). Dynamic capability emergence in the venture creation process. International Small Business Journal, 30(2), 138-160, CrossRef

- Covin, J. G., \& Slevin, D. P. (1989). Strategic management of small firms in hostile and benign environments. Strategic management journal, 10(1), 75-87, CrossRef

- Covin, J. G., \& Slevin, D. P. (1990). New venture strategic posture, structure, and performance: An industry life cycle analysis. Journal of business venturing, 5(2), 123-135, CrossRef

- Day, G. S. (1992). Marketing's contribution to the strategy dialogue. Journal of the Academy of Marketing Science, 20(4), 323-329, CrossRef

- Dess, G. G., Lumpkin, G. T., \& Covin, J. G. (1997). Entrepreneurial strategy making and firm performance: Tests of contingency and configurational models. Strategic management journal, 18(9), 677-695, CrossRef, CrossRef

- Dodgson, M. (1993). Organizational learning: a review of some literatures. Organization studies, 14(3), 375394, CrossRef

- $\quad$ Dougherty, D., \& Hardy, C. (1996). Sustained product innovation in large, mature organizations: Overcoming innovation-to-organization problems. Academy of Management Journal, 39(5), 1120-1153, CrossRef

- Eisenhardt, K. M., \& Martin, J. A. (2000). Dynamic capabilities: what are they? Strategic management journal, 21(10-11), 1105-1121, CrossRef

- Fernhaber, S. A., Mcdougall-Covin, P. P., \& Shepherd, D. A. (2009). International entrepreneurship: leveraging internal and external knowledge sources. Strategic Entrepreneurship Journal, 3(4), 297-320, CrossRef

- Fornell, C., \& Larcker, D. F. (1981). Evaluating structural equation models with unobservable variables and measurement error. Journal of marketing research, 39-50, CrossRef

- George, B. A., \& Marino, L. (2011). The epistemology of entrepreneurial orientation: Conceptual formation, modeling, and operationalization. Entrepreneurship Theory and Practice, 35(5), 989-1024, CrossRef

- Griffith, D. A., \& Harvey, M. G. (2001). A resource perspective of global dynamic capabilities. Journal of International Business Studies, 597-606, CrossRef

- Hair, J. F., Hult, G. T. M., Ringle, C., Sarstedt, M., \& (2013). A primer on partial least squares structural equation modeling (PLS -SEM. Thousand Oaks, California: SAGE Publications

- Hair, J. F., Ringle, C. M., \& Sarstedt, M. (2011). PLS-SEM: Indeed a silver bullet. The Journal of Marketing Theory and Practice, 19(2), 139-152, CrossRef

- Hair, J. F., Wolfinbarger, M. F., Ortinau, D. J., \& Bush, R. P. (2010). Essentials of marketing research: McGraw-Hill/Irwin.

- Helfat, C. E., Finkelstein, S., Mitchell, W., Peteraf, M., Singh, H., Teece, D., \& Winter, S. G. (2009). Dynamic capabilities: Understanding strategic change in organizations: Wiley.com.

- Henseler, J., Ringle, C. M., \& Sinkovics, R. R. (2009). The use of partial least squares path modeling in international marketing. Advances in international marketing, 20, 277-319, CrossRef

- Hou, J.-J. (2008). toward a research model of market orientation and dynamic capabilities. Social behavior and personality, 36(9), 1251, CrossRef

- Ibeh, K. I. (2004). Furthering export participation in less performing developing countries: The effects of entrepreneurial orientation and managerial capacity factors. International Journal of Social Economics, 31(1/2), 94-110, CrossRef

- Jantunen, A., Puumalainen, K., Saarenketo, S., \& Kyläheiko, K. (2005). Entrepreneurial orientation, dynamic capabilities and international performance. Journal of International Entrepreneurship, 3(3), 223-243, CrossRef

- Kaleka, A., \& Berthon, P. (2006). Learning and locale: The role of information, memory and environment in determining export differentiation advantage. Journal of Business Research, 59(9), 1016-1024, CrossRef

- Karim, S. (2006). Modularity in organizational structure: the reconfiguration of internally developed and acquired business units. Strategic Management Journal, 27(9), 799-823, CrossRef 
- Kaya, N., \& Patton, J. (2011). The effects of knowledge-based resources, market orientation and learning orientation on innovation performance: An empirical study of Turkish firms. Journal of International Development, 23(2), 204-219, CrossRef

- Kazem, A., \& van der Heijden, B. (2006). Exporting firms' strategic choices: the case of Egyptian SMEs in the food industry. SAM Advanced Management Journal, 71(3), 21.

- King, A. A., \& Tucci, C. L. (2002). Incumbent entry into new market niches: The role of experience and managerial choice in the creation of dynamic capabilities. Management Science, 48(2), 171-186, CrossRef

- Knight, G. A., \& Cavusgil, S. T. (2004). Innovation, organizational capabilities, and the born-global firm. Journal of International Business Studies, 35(2), 124-141, CrossRef

- Kock, N. (2011). Using WarpPLS in e-collaboration studies: Mediating effects, control and second order variables, and algorithm choices. International Journal of e-Collaboration (IJeC), 7(3), 1-13, CrossRef

- Kor, Y. Y., \& Mahoney, J. T. (2004). Edith Penrose's (1959) Contributions to the Resource-based View of Strategic Management. Journal of management studies, 41(1), 183-191, CrossRef

- Krejcie, R. V., \& Morgan, D. W. (1970). Determining sample size for research activities. Educ Psychol Meas.

- Laursen, K. (2002). The importance of sectoral differences in the application of complementary HRM practices for innovation performance. International Journal of the Economics of Business, 9(1), 139-156, CrossRef

- Lechner, C., \& Gudmundsson, S. V. (2014). Entrepreneurial orientation, firm strategy and small firm performance. International Small Business Journal, 32(1), 36-60, CrossRef

- Leonard-Barton, D. (1992). Core capabilities and core rigidities: A paradox in managing new product development. Strategic managementjournal, 13(S1), 111-125, CrossRef

- Lin, C., Jiang, J., Wu, Y.-J., \& Chang, C. (2011). Assessment of commercialization strategy using R\&D capability. Industrial Management \& Data Systems, 111(3), 341-369, CrossRef

- Miller, D. (1983). The correlates of entrepreneurship in three types of firms. Management science, 29(7), 770791, CrossRef

- Morgan, N. A., Kaleka, A., \& Katsikeas, C. S. (2004). Antecedents of export venture performance: a theoretical model and empirical assessment. Journal of Marketing, 68(1), 90-108, CrossRef

- Naman, J. L., \& Slevin, D. P. (1993). Entrepreneurship and the concept of fit: a model and empirical tests. Strategic management journal, 14(2), 137-153, CrossRef

- Newey, L. R., \& Zahra, S. A. (2009). The evolving firm: how dynamic and operating capabilities interact to enable entrepreneurship. British Journal of Management, 20(s1), S81-S100, CrossRef

- Nunnally, J. (1978). C.(1978). Psychometric theory: New York: McGraw-Hill.

- Ogunsiji, A. S. (2010). Entrepreneurial Orientation as a Panacea for the Ebbing Productivity in Nigerian Small and Medium Enterprises: A Theoretical Perspective. International Business Research, 3(4), P192, CrossRef

- Onugu, B. A. N. (2005). Small and medium enterprises (SMEs) in Nigeria: Problems and prospects. St. Clements University, Nigeria (Unpublished Dissertation for a Doctor of Philosophy in Management Award).

- Santos, F. M., \& Eisenhardt, K. M. (2009). Constructing markets and shaping boundaries: Entrepreneurial power in nascent fields. Academy of Management Journal, 52(4), 643-671, CrossRef

- Sapienza, H. J., Autio, E., George, G., \& Zahra, S. A. (2006). A capabilities perspective on the effects of early internationalization on firm survival and growth. Academy of Management Review, 31(4), 914-933, CrossRef

- Sekaran, U., \& Bougie, R. (2013). Research Methods for Business (6th ed.). United Kindom: John Wiley \& Son Ltd.

- Sinkula, J. M., Baker, W. E., \& Noordewier, T. (1997). A framework for market-based organizational learning: linking values, knowledge, and behavior. Journal of the academy of Marketing Science, 25(4), 305318, CrossRef

- Slater, S. F., \& Narver, J. C. (1995). Market orientation and the learning organization. The Journal of Marketing, 63-74, CrossRef

- Slater, S. F., \& Narver, J. C. (2000). The positive effect of a market orientation on business profitability: a balanced replication. Journal of business research, 48(1), 69-73, CrossRef

- Song, J. H., Joo, B. K. B., \& Chermack, T. J. (2009). The dimensions of learning organization questionnaire (DLOQ): a validation study in a Korean context. Human Resource Development Quarterly, 20(1), 43-64, CrossRef

- Souchon, A. L., Sy-Changco, J. A., \& Dewsnap, B. (2012). Learning orientation in export functions: impact on export growth. International Marketing Review, 29(2), 175-202, CrossRef

- Teece, D. J. (2007). Explicating dynamic capabilities: the nature and microfoundations of (sustainable) enterprise performance. Strategic management journal, 28(13), 1319-1350, CrossRef

- Teece, D. J., Pisano, G., \& Shuen, A. (1997). Dynamic capabilities and strategic management. Strategic management journal, 18(7), 509-533, CrossRef 
- Tippins, M. J., \& Sohi, R. S. (2003). IT competency and firm performance: is organizational learning a missing link? Strategic Management Journal, 24(8), 745-761, CrossRef

- Walter, A., Auer, M., \& Ritter, T. (2006). The impact of network capabilities andentrepreneurial orientation on university spin-off performance. Journal of Business Venturing, 21(4), 541-567, CrossRef

- Wang, C. L., \& Ahmed, P. K. (2007). Dynamic capabilities: A review and research agenda. International Journal of Management Reviews, 9(1), 31-51, CrossRef

- Wiklund, J. (1999). The sustainability of the entrepreneurial orientation-performance relationship. Entrepreneurship theory and practice, 24(1), 37-48.

- Wiklund, J., \& Shepherd, D. (2003). Knowledge-based resources, entrepreneurial orientation, and the performance of small and medium-sized businesses. Strategic management journal, 24(13), 1307-1314, CrossRef

- Wiklund, J., \& Shepherd, D. (2005). Entrepreneurial orientation and small business performance: a configurational approach. Journal of business venturing, 20(1), 71-91, CrossRef

- Woldesenbet, K., Ram, M., \& Jones, T. (2012). Supplying large firms: The role of entrepreneurial and dynamic capabilities in small businesses. International Small Business Journal, 30(5), 493-512, CrossRef

- Zahra, S. A., \& Covin, J. G. (1995). Contextual influences on the corporate entrepreneurship-performance relationship: A longitudinal analysis. Journal of business venturing, 10(1), 43-58, CrossRef

- Zahra, S. A., Sapienza, H. J., \& Davidsson, P. (2006). Entrepreneurship and dynamic capabilities: a review, model and research agenda*. Journal of Management studies, 43(4), 917-955, CrossRef

- Zollo, M., \& Winter, S. G. (2002). Deliberate learning and the evolution of dynamic capabilities. Organization science, 13(3), 339-351, CrossRef

- Zou, S., Taylor, C. R., \& Osland, G. E. (1998). The EXPERF scale: a cross-national generalized export performance measure. Journal of International Marketing, 37-58. 